\title{
International Instruments for Conservation and Sustainable Use of Plant Genetic Resources for Food and Agriculture: An Historical Appraisal
}

\author{
Andrea Sonnino \\ Biotechnologies and Agroindustry Division, Casaccia Research Centre, ENEA, Via Anguillarese 301, \\ 00060 Rome, Italy; andrea.sonnino@enea.it
}

Received: 22 September 2017; Accepted: 24 October 2017; Published: 1 November 2017

\begin{abstract}
This paper critically reviews the evolution of concepts and principles that inspired the adoption and enforcement of international instruments related to the conservation, exchange and sustainable use of plant genetic resources for food and agriculture, including agreements, governance and programs. The review spans from the pioneering attempts to regulate this matter, to the negotiations that led to the current regulatory framework, covering the creation of the Panel of Experts on Plant Exploration and Introduction of Food and Agriculture Organization (FAO) in 1965, the establishment of the International Board for Plant Genetic Resources (IBPGR) in 1974 and the FAO Commission on Plant Genetic Resources for Food and Agriculture in 1983, the adoption of the International Undertaking in 1983 and, more recently (2001), the International Treaty for Plant Genetic Resources for Food and Agriculture. The conceptual contribution, offered by Prof. Scarascia Mugnozza and other visionary scholars, to the establishment of these international instruments, is highlighted.
\end{abstract}

Keywords: governance; treaty; farmers' rights; gene banks

\section{Introduction}

Genetic resources for food and agriculture, including plants, animals, micro-organisms and invertebrates, play an essential role in feeding mankind. They ensure the strategic reservoir necessary to maintain efficient food production systems and to adapt them for new socio-economic and environmental conditions. They contribute to the delivery of vital ecosystem services, such as pollination and pest control. It is therefore strategically crucial to preserve diversity through sustainable use, including diversity both among and within species.

The exchange of genetic resources started at the dawn of agriculture. One of the earliest documented germplasm collecting trips was sent by Queen Hatshepsut of Egypt, to Punt, to collect incense trees for the royal gardens (about 1500 BC) [1]. Her successor, Tuthmose III, organized a mission to Syria to collect seeds, plants and trees [2]. There has been so much exchange of genetic resources throughout the history of agriculture that nowadays more than two thirds of all food is produced using genetic resources grown outside their areas of origin, generating a high interdependence among countries in regard to their food supply and production systems [3].

The importance of the conservation of genetic resources was recognized as early as 795 AD, when Charlemagne gave instructions by means of the decree, Capitulare de villis, to plant in each farm, 77 different plant food species [4]. Keeping control of genetic resources was considered crucial by China to preserve the silk production monopoly, but ultimately, they lost it in $550 \mathrm{AD}$, when two Nestorian monks smuggled silkworm eggs and mulberry seeds into the Byzantine Empire for Emperor Justinian I [5]. Another early attempt to regulate the use of plant genetic resources was made in 1414 AD, by the Venetian Senate, which reported that massive exploitation of cypress in Crete was 
putting it in danger of extinction, and therefore forbade exports of this strategic resource used for naval constructions [6]. Brazil banned any export of rubber trees or seeds to maintain a monopoly on the production of rubber, but the monopoly was broken in 1876, when Henry Wickham smuggled a large number of seeds and initiated rubber production in British colonies, such as Ceylon and Malaysia. Less than fifty years later, the Brazilian rubber industry was annihilated by competition from Southeast Asia [7].

Even if the history of deliberate or accidental international movement of genetic resources is as old as agriculture, it is only in the last 50 years that the scientific developments of germplasm exploration and the economic interests accrued by germplasm exploitation have prompted the exigency of organizing and regulating the conservation and use of genetic resources on a global level [8].

This paper critically reviews the evolution of concepts and principles that inspired the adoption and enforcement of international instruments related to the conservation, exchange and sustainable use of plant genetic resources (PGRs) for food and agriculture, including agreements, conventions, treaties, governance and programs. The most important international events relevant to the establishment and evolution of international instruments, related to the conservation and sustainable utilization of PGRs, are reported in Table 1, in chronological order. Concepts and principles underpinning the international dialogue and, as a consequence, the international instruments related to the conservation and sustainable utilization of the PGRs, are discussed, following a thematic order, disregarding the chronological sequence, in order to ensure an organic analysis. The intellectual contribution, offered by Prof. GianTommaso Scarascia Mugnozza and other visionary scholars, to the establishment of these international instruments is highlighted, along with the discussion of the conceptual evolution about PGRs [9]. More details on the history of the international regulation of PGR conservation and exchange are available in $[8,10-12]$.

\section{Evolution of Underpinning Concepts and Principles}

\subsection{Genetic Erosion}

The rapid expansion of plant breeding during the second half of the 20th century brought the introduction of a big number of improved varieties, which progressively replaced old landraces, especially in developing countries. Not all the genes present in the farmers' varieties are also contained in modern varieties. In addition, the release of commercial varieties into traditional farming systems often leads to a reduction in the number of varieties cultivated in a given area. This phenomenon was noticed and denounced as a peril by Harlan and Martini [13], and Frankel [14], among others. The term 'genetic erosion' was coined at the Technical Conference Plant Exploration, Utilization and Conservation of Plant Genetic Resources of FAO/IBP (International Biological Programme), held in Rome in 1967 [15], to describe this loss of individual genes and combinations of genes. At this conference, the genetic erosion issue was first systematically addressed, urging for a coordinated global programme of collection and conservation of PGRs. Erna Bennet from FAO and Otto Frankel from Australia were the major contributors to these concepts.

After the outbreak of corn-leaf blight in the United States of America (USA) and coffee rust in Brazil, the loss of genetic variability was identified as a cause of crop vulnerability to pests, diseases and other adverse factors [16]. Scarascia Mugnozza subsequently pointed out that genetic erosion is not only a problem of environmental significance, but it has also socio-economic, political and ethical relevance [17].

In 1991, the FAO Conference agreed that a report on the State of the World's PGRs should be prepared. The report was submitted at the Fourth International Technical Conference for the Conservation and Utilization of Plant Genetic Resources, in 1996 [18]. It has been an important global instrument to assess genetic erosion and to inform decision-making related to PGR management. The State of the World's PGRs identified the replacement of local varieties by modern varieties as the main cause of genetic erosion. Other causes of genetic erosion and loss of biodiversity included the emergence of 
new pests, weeds and diseases, habitat degradation, urbanization, land clearing through deforestation, and bush fires.

A Second Report on the State of the World's Plant Genetic Resources identified the most significant changes that occurred between 1996 and 2009 [19].

With the adoption of the Programme of Work on Climate Change and Genetic Resources for Food and Agriculture, in 2013 and the approval of the Voluntary Guidelines to Support the Integration of Genetic Diversity into National Climate Change Adaptation Planning, in 2015, attention was paid to climate change as major driver of genetic erosion. The importance of PGRs for coping with climate change was therein underlined.

\subsection{What to Conserve}

To counter genetic erosion, a number of exploration and collection missions were undertaken, especially after World War II. The problem arose about what to collect and conserve. At the beginning, germplasm collection expeditions adopted a 'mission-oriented approach', focusing on targets specific to single plant breeding projects [8]. The collected material was mainly used in small, purpose-specific collections, mostly located at plant breeding stations. It was objected that this approach, while responding to immediate individual or organizational needs, had little effect on genetic erosion. The opposite approach, called, by Frankel [20], a 'generalist approach', was directed towards collecting as much as possible, especially in plant centres of origin, and to conserve the collected materials in centralized ex situ gene banks, which serve networks of plant breeding programs. This approach was facilitated by the adoption of long-term cold storage facilities, developed in the 1960s.

The debate about the object of PGR conservation was, in the 1960s and 1970s, limited to the ambit of food and agriculture and dominated by the consideration of their economic and strategic values. The rise in concern about environmental degradation, especially during the process of preparation of the United Nations (UN) Conference on Environment and Development (UNCED) and the Convention on Biological diversity (CBD), prompted an international discussion on the conservation of biological diversity, on a large scale [21]. This debate led to the establishment of two parallel arenas: (i) an agricultural arena, based in the FAO and Consultative Group on International Agricultural Research (CGIAR), and focused on the use and economic value of genetic resources, and (ii) an environmental arena, grounded by the United Nations Environment Programme (UNEP) and conservationist organizations, and devoted to more general aspects, including those related to non-use and non-value of diversity [8]. These two political arenas often entered into conflict with each other, especially for allocation of financial resources, but also benefitted from exchange of ideas and concepts.

\subsection{How to Conserve and Use PGRs}

During the pioneering years, PGR-related activities were focused on the collection and ex situ conservation of germplasm. Although the value of ex situ collections remains undoubted by the scientific community, several scholars, including Erna Bennet and Robert Allard [15], expressed concern that the storage of seeds in gene banks does not allow natural evolution to happen, to create new diversity, and thus proposed to adopt in situ conservation strategies in [22,23]. Initially this proposal did not find unanimous support. The first formal acceptance of in situ conservation was given in 1973, by the FAO/IBP Technical Conference on Genetic Resources [8]. The concept was reinforced by the recommendations of the 1981 FAO/IBP Technical Conference on Genetic Resources. The 1996 Leipzig Declaration appropriated both the ex situ and in situ approaches, considering them as not mutually exclusive, but complementary components of conservation programmes.

The CBD explicitly promotes in situ conservation, through the establishment of protected areas and natural parks [11]. In addition, on-farm conservation is often adopted to grow, utilize and conserve 
landraces, native varieties and other local materials, within their original landscapes and traditional farming systems.

The community-based conservation approach, as proposed by M.S. Swaminathan, involves programs for local variety and landrace conservation in indigenous communities and/or rural families, who receive compensation and access to the stored PGRs, in exchange for their services [24]. The "Scarascia Mugnozza Community Genetic Resources Centre", established in Chennai, India with Italian funding [9], allows for the exchange of genetic resources between farmers of the same community and therefore the widening of the genetic basis of crops [25]. The Potato Park in Peru, where potato genetic resources are conserved by local communities, along with their cultural heritage, is another good example of application of this approach [26].

Integration of ex situ, in situ, on-farm and community-based approaches in PGR conservation strategies was advocated by Scarascia Mugnozza when he addressed the FAO Conference in 1995 [17].

\subsection{The Contribution of Biotechnologies to PGR Management}

The contribution of biotechnologies to decision-making in PGR management and mitigation of genetic erosion was recognized by several internationally-agreed documents [27]. Agenda 21, adopted by UNCED in 1992 (Table 1), explicitly recognizes the potential of biotechnology. Article 19 of the CBD also stated the need for further development of internationally-agreed principles on risk assessment and management of all aspects of biotechnology and established an Open-Ended Ad Hoc Working Group on Biosafety to develop a draft protocol on biosafety, specifically focusing on transboundary movements of living modified organisms (LMO), resulting from modern biotechnology, that may have adverse effects on the conservation and sustainable use of biological diversity. The Cartagena Protocol on Biosafety defines a living modified organism (LMO) as "any living organism that possesses a novel combination of genetic material, obtained through the use of modern biotechnology". In general, use of the term LMO is considered to be functionally the same as the term, genetically modified organism (GMO). After a long and complicated negotiation, in 2001, the CBD Conference of the Parties adopted the Cartagena Protocol on Biosafety (entered into force in 2003). The aim of the Protocol is to protect biological diversity from the potential environmental risks posed by LMOs. It established that an advance informed agreement (AIA) ensures that countries are provided with the information necessary to make informed decisions before agreeing to imports. The protocol references to a precautionary approach, as defined in Principle 15 of the Rio Declaration on Environment and Development. The protocol also establishes a Biosafety Clearing-House, to facilitate the exchange of information on LMOs.

The Commission on Genetic Resources for Food and Agriculture (CGRFA) has examined the developments in biotechnology, as they relate to conservation and use of PGRs, several times, starting from 1989, when it requested FAO to draft a Code of Conduct for Biotechnology. Preliminary drafts of this proposed legal instrument were examined by CGRFA, in 1991, 1993, and 1995. After several postponements, the possible adoption of a Code of Conduct was ultimately dropped, in consideration of the existence of other possibly overlapping international mechanisms. The drafts and the accompanying documents were nonetheless sent to the CBD secretariat and contributed to the negotiation of a biosafety protocol. CGRFA examined the advancements of biotechnologies in 1999 [28] and in 2011 [29], appreciating the contributions that biotechnologies were giving to both conservation and use of PGRs, calling for consideration and management of inherent risks, and urging for capacity development initiatives in developing countries. In particular, the decisive contributions offered by biotechnological approaches, especially from genomics and transcriptomics, to the measurement of plant genetic variation, to the protection of diversity, and to gene bank management, were underlined. A more comprehensive review of the biotechnologies, applied to the Management of Genetic Resources for Food and Agriculture, is presented in [30]. 
The current status of biotechnology development and application in naturally regenerated forests and in planted forests was examined by the International Symposium on Forest Biotechnology for Smallholders, held in Foz do Iguaçu, Brazil, in 2015 [31].

CGRFA paid more focused attention to the potential impacts of Genetic Use Restriction Technologies (GURTs) on agrobiodiversity, in 2002 [32]; and on genomics and genetic resources for food and agriculture, in 2007 [33]. The background paper on the effects of (trans)gene flow on the conservation and sustainable use of genetic resources, discussed by CGRFA in 2007, analysed the delicate issue of the preservation of the genetic identity of PGR specimens conserved in ex situ collections and the possible perils posed by their proximity with Genetically Modified Organisms (GMOs) [34].

Already in 1995, Scarascia Mugnozza had noted the intimate connection of biotechnology to biodiversity and warned FAO member countries about the danger of developing countries remaining excluded from the benefits of biotechnology application [17]. This concept was further reinforced by the International Technical FAO Conference on Agricultural biotechnologies in developing countries, held in Guadalajara, Mexico, in 2010 [35], where the possible benefits of biotechnologies for small farmers, producers and consumers were underlined. The FAO International Symposium on The role of agricultural biotechnologies in sustainable food systems and nutrition, held in 2016, reaffirmed that biotechnologies can be used, following agroecological principles, to enhance productivity, while ensuring sustainability, and to conserve genetic resources and use, and indigenous knowledge [36].

\subsection{Who Owns PGRs and How the Owners Should Be Compensated by the Users}

The 22nd Session of the FAO Conference, held in Rome in 1983, marked a breakthrough for the international regulation of PGRs, in that it adopted the first international, even if not legally binding, instrument to regulate conservation and use of PGRs, the International Undertaking on Plant Genetic Resources. It stated that "plant genetic resources should be considered as a common heritage of mankind and be available without restrictions for plant breeding, scientific and development purposes to all countries and institutions concerned" [37]. The common heritage principle was implicitly used as the principle governing the diffusion of PGRs from centers of domestication into new cultivation areas, since the discovery of the Americas and before [38]. The notion that while tropical countries hold the greatest deal of diversity, advanced countries, which hold the technical capacity to collect and use PGRs, benefit the most from their use [39] and that private companies were appropriating and exploiting developing countries' natural resources, without compensating them or even requesting their permission [12], sparked wide dissatisfaction among scientists and politicians of the third world. This unease was given a conceptual framework, with the publication of the book, The Seeds of the Earth: a Private or Public Resource, by Pat Mooney [40]. In recognition of this issue, third world representatives maintained that the Undertaking covered, in addition to landraces, wild species, and similar PGRs, "special genetic stocks (including elite and current breeders' lines)," which should also be made "available without restriction". This measure was opposed by private seed companies, supported by a number of developed countries that refused to sign the undertaking.

The 25th Session of the FAO Conference (1989) tried to conciliate the rights of developing and developed countries by adopting Resolution 4/89 (Agreed Interpretation of the Undertaking) and Resolution 5/89 [8]. The first document recognised that plant breeders' rights were not inconsistent with the international undertaking; the latter introduced the concept of farmers' rights, described as "rights arising from the past, present and future contributions of farmers in conserving, improving, and making available plant genetic resources, particularly those in the centers of origin/diversity." The resolution also stated that farmers' rights "are vested in the international community, as the trustee for present and future generations of farmers, for the purpose of ensuring full benefits to farmers, and supporting the continuation of their contributions." 
The Keystone Dialogues, held in 1988, 1990 and 1991, in Keystone, Madras (now Chennai) and Oslo respectively, and chaired by Prof. Mankombu Sambasivan Swaminathan, were instrumental in framing the issue of farmers' rights and providing a basis for their international recognition [41], as well as the recommendations which arose from two meetings of the Crucible Group [42]. The PGR ownership question was considered again by the 1991 FAO Conference. Resolution 3/91 stated that "the concept of mankind's heritage, as applied in the Undertaking on Plant Genetic Resources, is subject to the sovereignty of the states over their genetic resources". The CBD, in 1992, abandoned definitively, the concept of common heritage of mankind, when it stipulated that the nations hold sovereign rights on natural resources within their boundaries and that the authority to regulate access to PGRs rests with national governments, which are nevertheless requested to facilitate the access [12]. Resolution 3 of the Nairobi Final Act, adopted by countries in the framework of the CBD, included the famers' rights question among the outstanding, unsettled matters. The notion that famers contributed, and will keep contributing to, the conservation and development of PGRs, and that a financial mechanism to compensate this contribution should be established, was also asserted by Scarascia Mugnozza in front of the FAO Conference, in 1995 [17].

The official endorsement of farmers' rights and national sovereignty over PGRs arrived with the approval of the 2001 International Treaty on Plant Genetic Resources for Food and Agriculture (entered into force in 2004). Article 9 of the Treaty, recognizing the enormous contribution that farmers have made to the development of the world's wealth of PGRs, calls for ensuring that they share the benefits derived from the use of these resources. The responsibility for implementing farmers' rights is given to governments. The measures that could be taken to protect, promote and realize these rights are:

(a) Protection of traditional knowledge, relevant to PGRs;

(b) Ensuring the right to equitably participate in sharing benefits arising from the utilization of PGRs;

(c) Ensuring the right to participate in making decisions, on a national level, on matters related to the conservation and sustainable use of PGRs; and

(d) Safeguarding the farmers' rights to save, use, exchange and sell farm-saved seed/propagating materials, subject to national law and as appropriate.

The Treaty (Article 10) establishes the Multilateral System of Access and Benefit Sharing of PGRs. Access to PGRs is subject to the issue of a standard Material Transfer Agreement (MTA). Those who access genetic materials through the Multilateral System agree to pay to a financial mechanism, established by the Treaty, of an equitable share of the benefits arising from their commercial use (Article 13). With these provisions, the Treaty shifted the famers' rights issue from direct economic compensation, which would have been difficult to implement and would have had negative effects on access [8], to a social dimension. The benefit-sharing mechanism, settled by the Treaty, in fact recognizes the moral obligation towards the famers, who developed and maintained the PGRs, and generates resources for conservation and development of PGRs at large. The long negotiation that led to the adoption of the Treaty benefitted greatly from the contributions by José Esquinas-Alcázar from FAO [10].

\subsection{Ownership and Legal Status of Ex Situ Collections Held by International Agricultural Research Centres (IARCS)}

Since their establishment, the International Agricultural Research Centres (IARCs) of the CGIAR collected, conserved in their gene banks and utilized, hundreds of thousands of samples of PGRs, that formed the basis for the development of improved varieties, including those utilized in the green revolution [11]. The adoption of the international undertaking, and particularly Article 7, called for the development of an 'international network of collections in gene banks under the auspices or jurisdiction of FAO'. In compliance with the undertaking, the IARCs signed an agreement with FAO, placing their collection within this network [10]. Through this agreement, the IARCs were recognized 
as trustees of collections, renounced to claim ownership over the PGRs they conserved, and committed themselves to providing the international community with the designated germplasm.

While the ownership of national collections was usually vested in countries where the gene-banks were located, the ownership and legal status of ex situ collections, held by IARCs, was still unclear [8], especially in light of the provisions of the CBD. The convention, in fact, offers signing parties rights over their natural resources, even if the sovereign rights can be exerted only over PGRs of proved origin and acquired, after the entry into force of the CBD itself. Most the PGRs held by IARCS remain therefore excluded from this provision.

Article 15 of the International Treaty on Plant Genetic Resources for Food and Agriculture calls upon the IARCs to place their germplasm collections under the purview of the treaty. This was stipulated by agreements with the Governing Body of the Treaty, signed by IARCs and a number of other international centres [10]. IARCs began using the standard Material Transfer Agreement of the Treaty whenever transferring germplasm, using it not only for plants covered by the Treaty [43].

\subsection{Governance}

During the 1960s and the 1970s, FAO played the role of a practically unique international forum on PGRs. It was soon evident that PGR collection and conservation had not only technical, but also financial implications. The CGIAR, following the recommendations of the ad hoc Working Group of the Technical Advisory Committee (TAC) at its meeting, in Beltsville, in 1972, took a number of important decisions related to CGIAR base collections (see Table 1) and made a notable offer to cover the costs of a global conservation network [8]. This move brought aboutthe establishment of the International Board for Plant Genetic Resources (IBPGR), with the task of coordinating an international plant genetic resources programme, including emergency collecting missions, and building and expanding a network of national, regional and international gene banks [44]. To conciliate the technical and financial aspects of the PGR programme with the political facets of the PGR issue, the board was placed in FAO premises, and FAO acted as the secretariat. The story of collaboration between IBGR and FAO, even if quite conflictive, was at the end of the day fruitful, in that it complemented mutual functions [8]. In the last part of the 1980s, IBPGR acquired increased autonomy. In 1991, five countries signed the initial agreement that transformed IBPGR into the International Plant Genetic Resources Institute (IPGRI), with the CGIAR Centre being totally autonomous from the FAO [44] Forty-three additional countries joined the agreement at this second time [45]. The new institute is hosted by Italy [9]. Since 2006, the institute has used the name, Bioversity.

In 1983, the FAO Conference decided to establish the Commission on Plant Genetic Resources for Food and Agriculture (CPGRFA). The commission provides the only permanent forum for governments to discuss and negotiate matters relevant to genetic resources, including the sustainable use and conservation of PGRs and the fair and equitable sharing of benefits derived from their use. In 1995, the FAO Conference broadened the commission's mandate to cover all components of biodiversity, relevent to food and agriculture and modified its name into Commission on Genetic Resources for Food and Agriculture (CGRFA). With the entrance into force of the international treaty, all the matters related to its implementation became ruled by a Governing Body.

\subsection{Securing the International PGR Collections}

The history of collection, conservation and use of PGRs was constantly accompanied by underfunding problems, with the increasing volume of germplasm to be conserved conflicting with shrinking resources [46]. In addition, the financial endowment of gene banks is imperilled by political instabilities and fluctuations of stakeholders' commitments, not to mention wars, social unrest, natural disasters and other risks. The Global Crop Diversity Trust (now renamed Crop Trust) was established in 2004, as an independent organization under international law, that holds the permanent, self-sustaining Crop Diversity Endowment Fund. Each year, a portion of the fund's value, generated from investment income earned, is used to ensure the conservation and maintenance of 
PGRs held in gene banks. The purpose is to subtract international collections from political instabilities and ensure them a long-term, predictable funding source. Unfortunately, the endowment fund's target size of the Crop Trust has not been reached yet [46].

In 2008, the Svalbard Global Seed Vault was established in the Svalbard Islands, Norway. It is a fail-safe seed storage facility, built to protect PGRs held in traditional seed banks around the world from natural or man-made disasters and thus prevent the loss of crop diversity. The duplicated seed samples, conserved by the seed vault, have already been used to retrieve germplasm collections damaged by war events in Syria [46].

\section{Conclusions}

It is difficult to deny that concepts and principles supporting the international movement on the conservation and sustainable use of PGRs have greatly evolved during the last 50-60 years. Notions generated by a tiny group of visionary pioneers are now shared by the public at large and have become common knowledge. The evolution of scientific and political thinking, accompanied by the increase in public awareness, has allowed for the achievement of important results that can be summarized as follows:

(a) Approximately 7.4 million germplasm accessions, representing more than 16,500 plant species are currently secured in 1750 gene banks worldwide [19];

(b) Conserved germplasm provides broad genetic diversity that is increasingly used for genetic studies and plant breeding programs, with undeniable benefits for present and future world food production [47];

(c) Newly developed technologies, including molecular biology-based technologies, are greatly contributing to the conservation, exploration and characterization of PGRs, opening unprecedented opportunities for their sustainable utilization [30,31].

(d) The adoption of the International Treaty on Plant Genetic Resources for Food and Agriculture has provided a regulatory framework to access, exchange and benefit sharing of PGRs [10].

Consideration of the results achieved should not distract attention from the outstanding problems, the most important of which are:

(a) Genetic erosion is far from being stopped, as attested to by the Second Report on the State of the World's Plant Genetic Resources [19];

(b) Payment for environmental services, such as the in situ conservation of PGRs, is not always recognized, for farmers and local communities,

(c) Conservation programmes are chronically underfunded [46],

(d) The impact of climate change on crop genetic diversity is not fully understood,

(e) Appropriate capacities and adequate infrastructures to explore and exploit biodiversity are still lacking in many developing countries [46].

Finally, the transition towards sustainable food and agriculture systems urges us to integrate the genetic resource conservation and utilization issue into a holistic view of sustainability. Only a systems approach, that studies not only the single components, but also considers the interplay among them, can, in fact, indicate sustainable strategies to face the multiple challenges before us. 
Table 1. Events relevant to the establishment and evolution of international instruments related to the conservation and sustainable utilization of Plant Genetic Resources (PGRs).

\begin{tabular}{|c|c|c|c|}
\hline Year & Event & $\begin{array}{l}\text { Main Output(s) of Relevance for PGRs } \\
\text { and [Reference] }\end{array}$ & Underpinning Principle(s) \\
\hline 1961 & $\begin{array}{l}\text { FAO (Food abd Agriculture Organization) Technical Meeting } \\
\text { on Plant Exploration and Introduction, Rome, 10-20 July. }\end{array}$ & Report of the meeting. & $\begin{array}{l}\text { Mission-driven approach: } \\
\text { Conservation and use closely linked, tied to plant breeding, } \\
\text { dominance of ex situ collections, mainly in } \\
\text { developed countries. }\end{array}$ \\
\hline 1965 & $\begin{array}{l}\text { Establishment of the FAO Panel of Experts on Plant } \\
\text { Exploration and Introduction. }\end{array}$ & Six meetings between 1967 and 1975. & $\begin{array}{l}\text { Formulation of criteria for the conservation and use } \\
\text { of PGRs. }\end{array}$ \\
\hline 1967 & $\begin{array}{l}\text { FAO/IBP Technical Conference Plant Exploration, Utilization } \\
\text { and Conservation of Plant Genetic Resources, Rome, } 18-26 \\
\text { September. }\end{array}$ & Publication [15]. & $\begin{array}{l}\text { Generalist approach: } \\
\text { Rising concern about gene erosion of landraces and } \\
\text { wild relatives } \\
\text { Large, long-term ex situ collections } \\
\text { In situ conservation as a } \\
\text { complementary/alternative strategy. }\end{array}$ \\
\hline 1969 & $\begin{array}{l}\text { Third Session of the FAO Panel of Experts on Plant Exploration } \\
\text { and Introduction, Rome, 25-28 March. }\end{array}$ & Report [48]. & $\begin{array}{l}\text { List of priority geographic areas for exploration and } \\
\text { conservation of PGRs. }\end{array}$ \\
\hline 1971 & $\begin{array}{l}\text { Founding meeting of the Consultative Group on International } \\
\text { Agricultural Research (CGIAR), Washington, DC, USA, } 19 \\
\text { May } 1971 .\end{array}$ & $\begin{array}{l}\text { Resolution, establishment of the Technical } \\
\text { Advisory Committee. }\end{array}$ & Linkage between agricultural research and development. \\
\hline \multirow{3}{*}{1972} & $\begin{array}{l}\text { Issue of the report of the Agricultural Board of the National } \\
\text { Research Council. }\end{array}$ & [16] & Genetic uniformity as a cause of vulnerability to epidemics. \\
\hline & $\begin{array}{l}\text { UN Conference on Human Environment, } \\
\text { Stockholm, 5-16 June. }\end{array}$ & $\begin{array}{l}\text { Articles } 39-45 \text { of the United Nations (UN) } \\
\text { Declaration on the Human Environment. }\end{array}$ & $\begin{array}{l}\text { Genetic resources issue brought into the } \\
\text { international agenda. } \\
\text { Clear division of tasks between in situ (wild relatives) and } \\
\text { ex situ (cultivated plants) conservation. }\end{array}$ \\
\hline & $\begin{array}{l}\text { TAC (Technical Advisory Committee) Ad Hoc Working } \\
\text { Group, Beltsville, 20-25 March. }\end{array}$ & $\begin{array}{l}\text { Report on The Collection, Evaluation and } \\
\text { Conservation of Plant Genetic Resources. }\end{array}$ & $\begin{array}{l}\text { Establishment of the World Network of Genetic } \\
\text { Resources Centres } \\
\text { Establishment of a coordinating centre } \\
\text { Support to gene banks already existing in International } \\
\text { Agricultural Research Centres (IARCs) of the CGIAR; } \\
\text { Establishment of additional gene banks in other IARCs of } \\
\text { the CGIAR. }\end{array}$ \\
\hline 1973 & $\begin{array}{l}\text { FAO/IBP Technical Conference on Genetic Resources, 12-16 } \\
\text { March, Rome. }\end{array}$ & Plan of action [49]. & Recommendation to establish in situ collections. \\
\hline
\end{tabular}


Table 1. Cont.

\begin{tabular}{|c|c|c|c|}
\hline Year & Event & $\begin{array}{l}\text { Main Output(s) of Relevance for PGRs } \\
\text { and [Reference] }\end{array}$ & Underpinning Principle(s) \\
\hline 1974 & $\begin{array}{l}\text { Establishment of the International Board for Plant Genetic } \\
\text { Resources (IBPGR). }\end{array}$ & [44] & $\begin{array}{l}\text { Coordination of an international PGR programme. } \\
\text { FAO acted as secretariat. }\end{array}$ \\
\hline \multirow[b]{2}{*}{1981} & $\begin{array}{l}\text { FAO/IBP Technical Conference on Genetic Resources, } \\
\text { 12-16 March, Rome. }\end{array}$ & Publication [50]. & $\begin{array}{l}\text { In situ collections best method to conserve variability of } \\
\text { wild species. }\end{array}$ \\
\hline & 21st Session of the FAO Conference, Rome, 7-25 November. & Resolution 6/81. & $\begin{array}{l}\text { Need for an international agreement to ensure the } \\
\text { conservation, maintenance and free exchange of PGRs } \\
\text { Requests FAO to prepare projects for two options: an } \\
\text { international agreement and an international gene bank. }\end{array}$ \\
\hline 1983 & $\begin{array}{l}\text { 22nd Session of the FAO Conference, Rome, } \\
5-23 \text { November. }\end{array}$ & $\begin{array}{l}\text { Resolution 8/83: } \\
\text { Adoption of the International Undertaking } \\
\text { on Plant Genetic Resources } \\
\text { Establishment of the Commission on Plant } \\
\text { Genetic Resources for Food and Agriculture } \\
\text { (CGRFA) and of the Global System on Plant } \\
\text { Genetic Resources [51]. }\end{array}$ & $\begin{array}{l}\text { Shared principles, non-legally binding, on conservation and } \\
\text { access to PGRs: } \\
\text { PGRs are a common heritage of humankind } \\
\text { Genetic stocks and breeding lines included } \\
\text { Freedom of exchange through a network of gene banks } \\
\text { Supervision through the Commission. }\end{array}$ \\
\hline \multirow{3}{*}{1989} & $\begin{array}{l}\text { 25th Session of the FAO Conference, Rome, } \\
\text { 11-29 November. }\end{array}$ & $\begin{array}{l}\text { Resolution 4/89: } \\
\text { Adoption of an agreed interpretation of the } \\
\text { international undertaking. } \\
\text { Resolution 5/89: } \\
\text { Farmers' rights. }\end{array}$ & $\begin{array}{l}\text { Plant breeders' rights are not inconsistent with the } \\
\text { International Undertaking, Recognition of Farmers' Rights. }\end{array}$ \\
\hline & \multirow{2}{*}{ 3rd Regular Session of CGRFA, Rome, 17-21 April. } & $\begin{array}{l}\text { Call for the development of The } \\
\text { International Network of Ex Situ Collections } \\
\text { under the Auspices of FAO. }\end{array}$ & $\begin{array}{l}\text { Lack of clarity regarding the legal situation of the ex situ } \\
\text { collections. }\end{array}$ \\
\hline & & Report & $\begin{array}{l}\text { The Commission requested FAO to draft a code of conduct } \\
\text { for biotechnology, as it affects conservation and use of } \\
\text { genetic resources. }\end{array}$ \\
\hline \multirow[b]{2}{*}{1991} & \multirow[b]{2}{*}{ 26th Session of the FAO Conference, Rome, 9-27 November. } & $\begin{array}{l}\text { Transformation of the IBPGR into the } \\
\text { International Plant Genetic Resources } \\
\text { Institute (IPGRI). }\end{array}$ & Independence of IPGRI. \\
\hline & & Resolution 3/91. & $\begin{array}{l}\text { Recognition of the sovereign rights of nations over their } \\
\text { PGRs } \\
\text { Agreement on the development of the 1st State of the } \\
\text { World's Plant Genetic Resources and Global Plan of Action } \\
\text { on PGRs. }\end{array}$ \\
\hline
\end{tabular}


Table 1. Cont

\begin{tabular}{|c|c|c|c|}
\hline Year & Event & $\begin{array}{l}\text { Main Output(s) of Relevance for PGRs } \\
\text { and [Reference] }\end{array}$ & Underpinning Principle(s) \\
\hline \multirow{4}{*}{1992} & \multirow{4}{*}{$\begin{array}{l}\text { UN Conference on Environment and Development (UNCED) } \\
\text { Rio de Janeiro, 3-14 June. }\end{array}$} & $\begin{array}{l}\text { Convention on Biological Diversity (CBD) } \\
\text { (entered into force on } 29 \text { December 1993). }\end{array}$ & $\begin{array}{l}\text { Biodiversity vs. genetic resources } \\
\text { Need for a protocol setting out appropriate procedures for } \\
\text { safe transfer, handling and use of any living modified } \\
\text { organism resulting from biotechnology that may have } \\
\text { adverse effects on the conservation and sustainable use of } \\
\text { biological diversity } \\
\text { Establishment of the Open-ended Ad Hoc Working Group } \\
\text { on Biosafety. }\end{array}$ \\
\hline & & Chapter 14 of Agenda 21. & $\begin{array}{l}\text { Call for the strengthening of the FAO Global System on Plant } \\
\text { Genetic Resources. }\end{array}$ \\
\hline & & Chapter 16 of Agenda 21. & $\begin{array}{l}\text { Biotechnology can assist in the conservation of biological } \\
\text { resources through, for example, ex situ techniques } \\
\text { Need for further development of internationally-agreed } \\
\text { principles on risk assessment and management of all } \\
\text { aspects of biotechnology. }\end{array}$ \\
\hline & & $\begin{array}{l}\text { Adoption of Resolution } 3 \text { of the Nairobi } \\
\text { Final Act. }\end{array}$ & $\begin{array}{l}\text { Recognises matters not addressed by the convention: } \\
\text { Access to ex situ collections } \\
\text { The questions surrounding farmers' rights } \\
\text { Requests FAO forum to address these matters. }\end{array}$ \\
\hline \multirow[t]{2}{*}{1994} & 1st Extraordinary Session of the CGRFA. & $\begin{array}{l}\text { Start of negotiations for the revision of the } \\
\text { international undertaking, } 12 \text { centres of the } \\
\text { CGIAR sign an agreement with FAO, } \\
\text { placing their collections under the auspices } \\
\text { of FAO. }\end{array}$ & $\begin{array}{l}\text { Centres agree to hold the designated germplasm "in trust } \\
\text { for the benefit of the international community". }\end{array}$ \\
\hline & $\begin{array}{l}\text { Establishment of the "Scarascia Mugnozza Community } \\
\text { Genetic Resources Centre", Chennai. }\end{array}$ & {$[25]$} & Community-based conservation of PGRs. \\
\hline
\end{tabular}


Table 1. Cont

\begin{tabular}{|c|c|c|c|}
\hline Year & Event & $\begin{array}{l}\text { Main Output(s) of Relevance for PGRs } \\
\text { and [Reference] }\end{array}$ & Underpinning Principle(s) \\
\hline 1995 & 28th Session of the FAO Conference, Rome, 20 October. & $\begin{array}{l}\text { 19th McDougall Memorial Lecture "The } \\
\text { protection of biodiversity and the conservation } \\
\text { and use of genetic resources for food and } \\
\text { agriculture: potential and perspectives" by } \\
\text { G.T. Scarascia Mugnozza [17]. }\end{array}$ & $\begin{array}{l}\text { Biodiversity loss is not only an important environmental } \\
\text { problem, but also a socio-economic, political and ethical } \\
\text { problem } \\
\text { Conservation and access to PGRs are essential interests of } \\
\text { humankind and are strictly interconnected with food } \\
\text { security issues, } \\
\text { Exploration and ex situ conservation of PGRs are essential } \\
\text { but must be integrated by in situ, on farm, a } \\
\text { community-level conservation strategy, } \\
\text { PGRs should be conserved and made available to scientists } \\
\text { and farmers, but access should be regulated by } \\
\text { international agreements } \\
\text { Farmers, especially those who work in centres of origin of } \\
\text { cultivated plant species, contributed and will contribute, to } \\
\text { the conservation and development of PGRs; a financial } \\
\text { mechanism to compensate this contribution (Farmers' rights) } \\
\text { should be established } \\
\text { There is also a need to develop equitable mechanisms for } \\
\text { technological transfer from industrialized countries to } \\
\text { developing countries. }\end{array}$ \\
\hline \multirow{3}{*}{1996} & $\begin{array}{l}\text { Science Academies Summit at the M.S. Swaminathan } \\
\text { Research Foundation, 8-11 July, Madras. }\end{array}$ & Madras Declaration. & $\begin{array}{l}\text { Appealed to scientists of the world for the maintenance and } \\
\text { use of biodiversity of genetic resources important for food } \\
\text { and agriculture. }\end{array}$ \\
\hline & $\begin{array}{l}\text { 4th International Technical Conference on Plant Genetic } \\
\text { Resources, Leipzig, 17-23 June. }\end{array}$ & $\begin{array}{l}\text { Leipzig Declaration, Global Plan for } \\
\text { Conservation and of Sustainable Utilization of } \\
\text { PGRs for Food and Agriculture [52], State of } \\
\text { the World's PGRs [18]. }\end{array}$ & $\begin{array}{l}\text { Appropriation of in situ and ex situ approaches } \\
\text { Fair and equitable sharing of benefits arising for the use of } \\
\text { genetic resources. }\end{array}$ \\
\hline & World Food Summit, Rome, 13-17 November. & $\begin{array}{l}\text { Solemn support to Leipzig Plan of } \\
\text { Action [52]. }\end{array}$ & \\
\hline 1999 & $\begin{array}{l}\text { 1st Extraordinary meeting of the Conference of the Parties } \\
\text { to the CBD, Cartagena, Colombia, } 22 \text { February. }\end{array}$ & Decision EM-I/1. & \\
\hline
\end{tabular}


Table 1. Cont

\begin{tabular}{|c|c|c|c|}
\hline Year & Event & $\begin{array}{l}\text { Main Output(s) of Relevance for PGRs } \\
\text { and [Reference] }\end{array}$ & Underpinning Principle(s) \\
\hline 2000 & $\begin{array}{l}\text { Resumed Session of the Conference of the Parties to the } \\
\text { CBD, Montreal, Canada, 24-29 January. }\end{array}$ & $\begin{array}{l}\text { Adoption of the Cartagena protocol on } \\
\text { biosafety to the convention on biological } \\
\text { diversity (decision EM-I/3). }\end{array}$ & $\begin{array}{l}\text { Protect biological diversity from the potential risks posed } \\
\text { by living modified organisms (LMOs) resulting from } \\
\text { modern biotechnology } \\
\text { Advance informed agreement (AIA) procedure, for } \\
\text { transboundary movements of LMOs } \\
\text { Reference to a precautionary approach, } \\
\text { Biosafety Clearing-House to facilitate the exchange of } \\
\text { information on LMOs. }\end{array}$ \\
\hline 2001 & 31st Session of the FAO Conference, Rome, 2-13 November. & $\begin{array}{l}\text { Resolution 3/2001: adoption of the } \\
\text { International Treaty for Plant Genetic } \\
\text { Resources (ITPGR) (entered into force on } 11 \\
\text { September 2004). }\end{array}$ & $\begin{array}{l}\text { Legally binding, } \\
\text { Recognition of farmers' rights } \\
\text { Access to PGRs } \\
\text { Fair and equitable sharing of the benefits derived from PGR } \\
\text { use. }\end{array}$ \\
\hline \multirow[t]{2}{*}{2002} & $\begin{array}{l}\text { 6th Ordinary Meeting of the Conference of the Parties to the } \\
\text { Convention on Biological Diversity, The Hague, } \\
\text { Netherlands, 7-19 April. }\end{array}$ & $\begin{array}{l}\text { Decision VI/26: Strategic Plan for the } \\
\text { Convention on Biological Diversity } \\
\text { 2002-2010. }\end{array}$ & $\begin{array}{l}\text { Biodiversity is the living foundation for sustainable } \\
\text { development } \\
\text { The rate of loss is still accelerating } \\
\text { The threats must be addressed, } \\
\text { The convention is an essential instrument for achieving } \\
\text { sustainable development. }\end{array}$ \\
\hline & $\begin{array}{l}\text { UN World Summit on Sustainable Development, Johannesburg, } \\
\text { South Africa, } 26 \text { August-6 September. }\end{array}$ & $\begin{array}{l}\text { Johannesburg declaration on sustainable } \\
\text { development. }\end{array}$ & $\begin{array}{l}\text { Emphasis on social and economic aspects of sustainable } \\
\text { development. }\end{array}$ \\
\hline 2004 & $\begin{array}{l}\text { Establishment of the Global Crop Diversity Trust (now } \\
\text { renamed Crop Trust). }\end{array}$ & $\begin{array}{l}\text { Endowment fund, the income from which } \\
\text { will be used to support the conservation of } \\
\text { distinct and important crop diversity, in } \\
\text { perpetuity, through existing institutions. }\end{array}$ & $\begin{array}{l}\text { Ensuring an absolutely dependable source of funding for } \\
\text { the conservation of PGRs. }\end{array}$ \\
\hline
\end{tabular}


Table 1. Cont

\begin{tabular}{|c|c|c|c|}
\hline Year & Event & $\begin{array}{l}\text { Main Output(s) of Relevance for PGRs } \\
\text { and [Reference] }\end{array}$ & Underpinning Principle(s) \\
\hline 2005 & Publication of the Millennium Ecosystem Assessment. & Ecosystems and human well-being [53]. & $\begin{array}{l}\text { Over the past } 50 \text { years, humans have changed ecosystems } \\
\text { more rapidly and extensively than in any comparable } \\
\text { period of time, to meet rapidly growing demands for food, } \\
\text { fresh water, timber, fiber, and fuel } \\
\text { The changes made have contributed to substantial net gains } \\
\text { in human well-being, but at growing environmental costs } \\
\text { Degradation of ecosystem services could grow significantly } \\
\text { worse during the first half of this century and is a barrier to } \\
\text { achieving the Millennium Development Goals, } \\
\text { Reversing the degradation of ecosystems, while meeting } \\
\text { increasing demands for their services can be partially met, } \\
\text { but involve significant changes in policies, institutions, and } \\
\text { practices that are not currently under way. }\end{array}$ \\
\hline \multirow{3}{*}{2006} & \multirow{3}{*}{$\begin{array}{l}\text { 1st meeting of the Governing Body of International Treaty } \\
\text { for Plant Genetic Resources (ITPGR), Madrid, 12-16 June. }\end{array}$} & $\begin{array}{l}\text { Standard Material Transfer Agreement } \\
\text { (SMTA). }\end{array}$ & $\begin{array}{l}\text { Regulation of the access to and use of PGRs. SMTA is the } \\
\text { legal instrument through which the Multilateral System of } \\
\text { Access and Benefit Sharing operates. }\end{array}$ \\
\hline & & $\begin{array}{l}\text { Relationship agreement between the } \\
\text { governing body of the treaty and Global } \\
\text { Crop Diversity Fund. }\end{array}$ & $\begin{array}{l}\text { Recognition of the Crop Trust as an "essential element" of } \\
\text { the treaty's funding strategy, in regard to ex situ } \\
\text { conservation and availability of PGRs, and as an } \\
\text { independent scientific organization in raising and } \\
\text { disbursing funds. }\end{array}$ \\
\hline & & $\begin{array}{l}\text { Agreements between the governing body } \\
\text { and } 12 \text { international agricultural research } \\
\text { centers (including the Centro Agronómico } \\
\text { Tropical de Investigación y } \\
\text { Enseñanza-CATIE). }\end{array}$ & $\begin{array}{l}\text { Ex situ gene bank collections are put under the ITPGR } \\
\text { (replaces agreement between IARCs and FAO). }\end{array}$ \\
\hline 2008 & $\begin{array}{l}\text { Establishment of the Svalbard Global Seed Vault, Svalbard, } \\
26 \text { February. }\end{array}$ & & Long term conservation. \\
\hline \multirow[b]{2}{*}{2009} & 12th Regular Session of the CGRFA, Rome, 19-23 October. & $\begin{array}{l}\text { 2nd report on the state of the world's plant } \\
\text { genetic resources [19]. }\end{array}$ & \\
\hline & $\begin{array}{l}\text { 36th Session of the FAO Conference, Rome, } \\
18-23 \text { November. }\end{array}$ & Resolution 18/2009. & $\begin{array}{l}\text { Special nature of PGRs in the context of negotiations of the } \\
\text { International Regime on Access and Benefit-Sharing of the } \\
\text { CBD. }\end{array}$ \\
\hline
\end{tabular}


Table 1. Cont

\begin{tabular}{|c|c|c|c|}
\hline Year & Event & $\begin{array}{l}\text { Main Output(s) of Relevance for PGRs } \\
\text { and [Reference] }\end{array}$ & Underpinning Principle(s) \\
\hline \multirow{3}{*}{2010} & $\begin{array}{l}\text { International Technical FAO Conference on Agricultural } \\
\text { biotechnologies in developing countries: Options and } \\
\text { opportunities in crops, forestry, livestock, fisheries and } \\
\text { agro-industry to face the challenges of food insecurity and climate } \\
\text { change (ABDC-10), Guadalajara; Mexico, 1-4 March } 2010 .\end{array}$ & Report [35]. & $\begin{array}{l}\text { Agricultural biotechnologies are being applied to an } \\
\text { increasing extent, } \\
\text { But they have not been widely used in many developing } \\
\text { countries, and have not sufficiently benefited smallholder } \\
\text { farmers and producers and consumers. }\end{array}$ \\
\hline & \multirow[t]{2}{*}{$\begin{array}{l}\text { 10th meeting of the Conference of the Parties to the } \\
\text { Convention on Biological Diversity, Nagoya, Japan, } \\
\text { 18-29 October. }\end{array}$} & $\begin{array}{l}\text { Decision X/1: Nagoya Protocol on Access to } \\
\text { Genetic Resources and the Fair and Equitable } \\
\text { Sharing of Benefits Arising from their } \\
\text { Utilization (ABS) to the Convention on } \\
\text { Biological Diversity (entered into force on } \\
12 \text { October 2014). }\end{array}$ & $\begin{array}{l}\text { Establishing more predictable conditions for access to } \\
\text { genetic resources, } \\
\text { helping to ensure benefit-sharing when genetic resources } \\
\text { leave the country providing the genetic resources } \\
\text { Also covers traditional knowledge, associated with genetic } \\
\text { resources. }\end{array}$ \\
\hline & & $\begin{array}{l}\text { Decision X/2: II Strategic Plan for } \\
\text { Biodiversity, including the Aichi } \\
\text { Biodiversity Targets, } \\
\text { for the 2011-2020 period. }\end{array}$ & $\begin{array}{l}\text { Recognition that the objectives of the 1st Strategic Plan } \\
\text { were not achieved } \\
\text { Establishment of twenty headline Aichi Biodiversity Targets } \\
\text { for } 2015 \text { or 2020, organized under five strategic goals. }\end{array}$ \\
\hline \multirow[t]{2}{*}{2011} & 13th Regular Session of the CGRFA, Rome, 18-22 July 2011. & $\begin{array}{l}\text { Background paper CGRFA-13/11/3 Status } \\
\text { and trends of biotechnologies applied to the } \\
\text { conservation and utilization of genetic } \\
\text { resources for food and agriculture and matters } \\
\text { relevant for their future development. }\end{array}$ & $\begin{array}{l}\text { Biotechnologies largely used for conservation and use of } \\
\text { PGRs } \\
\text { Many developing countries miss capacities. }\end{array}$ \\
\hline & $\begin{array}{l}\text { 143rd Session of the FAO Council, Rome, } \\
28 \text { November-2 December. }\end{array}$ & $\begin{array}{l}\text { Second global plan of action for the } \\
\text { conservation and sustainable utilization } \\
\text { of PGRs. }\end{array}$ & $\begin{array}{l}\text { Need for a roadmap on climate change and genetic } \\
\text { resources for food and agriculture. }\end{array}$ \\
\hline 2012 & $\begin{array}{l}\text { United Nations Conference on Sustainable Development } \\
\text { (UNCSD), also known as Rio 2012, Rio+20, Rio de Janeiro, } \\
\text { Brazil, 13-22 June. }\end{array}$ & Outcome document The Future We Want. & $\begin{array}{l}\text { Necessity to promote, enhance and support more } \\
\text { sustainable agriculture [... ] that improves food security, } \\
\text { eradicates hunger and is economically viable, while } \\
\text { conserving land, water, plant and animal genetic resources, } \\
\text { biodiversity and ecosystems and enhancing resilience to } \\
\text { climate change and natural disasters. }\end{array}$ \\
\hline 2013 & 14th Regular Session of the CGRFA, Rome, 15-19 April. & $\begin{array}{l}\text { Programme of work on climate change and } \\
\text { genetic resources for food and agriculture. }\end{array}$ & $\begin{array}{l}\text { Importance of genetic resources for food and agriculture for } \\
\text { coping with climate change. }\end{array}$ \\
\hline
\end{tabular}


Table 1. Cont.

\begin{tabular}{llll}
\hline Year & Event & $\begin{array}{l}\text { Main Output(s) of Relevance for PGRs } \\
\text { and [Reference] }\end{array}$ & Underpinning Principle(s) \\
\hline \multirow{2}{*}{2015} & $\begin{array}{l}\text { International Symposium on Forest Biotechnology for } \\
\text { Smallholders, Foz do Iguaçu, Paraná, Brazil, } \\
\text { 19-22 May 2015. }\end{array}$ & Background paper [31]. & $\begin{array}{l}\text { Biotechnologies largely used for both planted and naturally } \\
\text { regenerated forests. }\end{array}$ \\
\cline { 2 - 3 } $2016 \quad \begin{array}{l}\text { FAO International Symposium on The role of agricultural } \\
\text { biotechnologies in sustainable food systems and nutrition, Rome, } \\
\text { 15-17 February. }\end{array}$ & $\begin{array}{l}\text { Support the Integration of Genetic Diversity } \\
\text { into National Climate Change Adaptation } \\
\text { Planning. }\end{array}$ & $\begin{array}{l}\text { Importance of genetic resources for food and agriculture for } \\
\text { coping with climate change. }\end{array}$ \\
\hline
\end{tabular}


Acknowledgments: The critical reading of the manuscript prior to its submission by Barbara Di Giovanni and Laura Padovani, ENEA, is gratefully acknowledged. The author is also very grateful to the anonymous peer reviewers, who offered very valuable comments.

Conflicts of Interest: The author declares no conflict of interest.

\section{References}

1. Harlan, J.R. Crops and Man; American Society of Agronomy: Madison, WI, USA, 1992.

2. Ryder, E.J. Perspectives on germplasm. HortScience 2003, 38, 922-927.

3. Khoury, C.K.; Achicanoy, H.A.; Bjorkman, A.D.; Navarro Racines, C.; Guarino, L.; Flores Palacios, X.; Struik, P.C. Estimation of Countries' Interdependence in Plant Genetic Resources Provisioning National Food Supplies and Production Systems; The International Treaty on Plant Genetic Resources for Food and Agriculture: Rome, Italy, 2015.

4. Avanzato, D.; Vassallo, I. Following Almond Footprints (Amygdalis communis L.). Cultivation and Culture, Folk and History, Tradition and Uses; ISHS: Leuven, Belgium, 2006.

5. Cherry, R.H. History of sericulture. Bull. Entomol. Assoc. Am. 1987, 33, 83-85. [CrossRef]

6. Baumann, H. The Greek Plant Word: In Myth, Art and Literature; Timber Press: Portland, Oregon, 1993.

7. Foltz, J.D. Valuation and ownership of genetic resources in agriculture. In Public Policy in Food and Agriculture; EOLSS Publishers: Paris, France, 2009; pp. 260-286.

8. Pistorius, R. Scientists, Plants and Politics-A History of the Plant Genetic Resources Movement; IPGRI: Rome, Italy, 1997.

9. Sonnino, A. Internazionalizzazione della ricerca e cooperazione scientifica internazionale—L'attualità dell'insegnamento di Gian Tommaso Scarascia Mugnozza. Rendiconti dell'Accademia delle Scienze 2015, XXXIX, 203-216.

10. Esquinas-Alcázar, J.; Hilmi, A.; López Noriega, I. A Brief History of the Negotiations on the International Treaty on Plant Genetic Resources for Food and Agriculture; FAO: Rome, Italy, 2012.

11. Scarascia-Mugnozza, G.T.; Perrino, P. The history of ex situ conservation and use of plant genetic resources. In Managing Plant Genetic Diversity; Engels, V., Ramanatha, R., Brown, A., Jackson, M.T., Eds.; CABI Publishing: New York, NY, USA, 2002; pp. 1-22.

12. Sullivan, S.N. Plant Genetic Resources and the Law: Past, Present, and Future. Plant Physiol. 2004, 135, $10-15$. [CrossRef] [PubMed]

13. Harlan, H.V.; Martini, M.L. Problems and results in barley breeding. Yearb. Agric. 1936, 1936, 303-346.

14. Frankel, O.H. The development and maintenance of superior genetic stocks. Heredity 1950, 4, 89-102. [CrossRef] [PubMed]

15. Frankel, O.H.; Bennet, E. Genetic Resources in Plants-Their Exploration and Conservation; Blackwell Scientific: Oxford, UK, 1970.

16. National Research Council. Genetic Vulnerability of Major Crops; National Academy of Sciences: Washington, DC, USA, 1972.

17. Scarascia Mugnozza, G.T. The Protection of Biodiversity and the Conservation and Use of Genetic Resources for Food and Agriculture: Potential and Perspectives; FAO: Rome, Italy, 1995.

18. FAO. Report on the State of the World's Plant Genetic Resources; FAO: Rome, Italy, 1998.

19. FAO. The Second Report on the State of the World's Plant Genetic Resources; FAO: Rome, Italy, 2010.

20. Frankel, O.H. Conservation of crop genetic resources and their wild relatives: On overview. In Crop Genetic Resources for Today and Tomorrow; Frankel, O.H., Hawkes, J.G., Eds.; Cambridge University Press: Cambridge, UK, 1975.

21. Padovani, L.M.; Carrabba, P.; Di Giovanni, B.; Mauro, F. Biodiversità-Risorse per lo Sviluppo; ENEA: Rome, Italy, 2009.

22. Bennet, E. FAO/IBP Technical Conference on the Exploration, Utilization and Conservation of Plant Genetic Resources; FAO: Rome, Italy, 1968.

23. Hawkes, J.G. International workshop on dynamic in situ conservation of wild relatives of major cultivated plants: Summary of final discussion and recommendations. Israel. J. Bot. 1991, 40, 529-536.

24. Swaminathan, M.S. The Past, Present and Future Contributions of Farmers to the Conservation and Development of Genetic Diversity. In Managing Plant Genetic Diversity; Engels, J.M.M., Rao, V.R., Brown, A., Jackson, M.T., Eds.; CABI Publishing: New York, NY, USA, 2002; pp. 23-32. 
25. Bala Ravi, S.; Rani, M.G.; Swaminathan, S. Conservation of plant genetic resources at the Scarascia Mugnozza. In Memorie di Scienze Fisiche e Naturali; Aracne Editrice: Rome, Italy, 2010; pp. 47-58.

26. Argumedo, A. The Potato Park, Peru: Conserving agrobiodiversity in an Andean Indigenous Biocultural Heritage Area. In Protected Landscapes and Agrobiodiversity Values; Amend, T., Brown, J., Kothari, A., Phillips, A., Stolton, S., Eds.; Kasparek Verlag: Heidelberg, Germany, 2008; pp. 45-58.

27. Sonnino, A. Biodiversidad y biotecnologías: El eslabón estratégico. In Biodiversidad, Biotecnologia y Derecho un Crisol Para la Sustentabilidad; Ivone, V., Ed.; Aracne Editrice: Rome, Italy, 2011; pp. 299-320.

28. Spillane, C. Recent Developments in Biotechnology as They Relate to Plant Genetic Resources for Food and Agriculture; FAO: Rome, Italy, 1999.

29. Lidder, P.; Sonnino, A. Biotechnologies for the Management of Genetic Resources for Food and Agriculture, Commission on Genetic Resources for Food and Agriculture; FAO: Rome, Italy, 2011.

30. Lidder, P.; Sonnino, A. Biotechnologies for the Management of Genetic Resources for Food and Agriculture. Adv. Genet. 2012, 78, 1-168. [PubMed]

31. Sonnino, A. Current status of biotechnology development and application in forestry. In Proceedings of the International Symposium on Forest Biotechnology for Smallholders, Foz do Iguaçu, Paraná, Brazil, 19-22 May 2015; FAO: Rome, Italy, 2015.

32. Visser, B.; Eaton, D.; Louwaars, N.; van der Meer, I.; Beekwilder, J.; van Tongeren, F. Potential Impacts of Genetic Use Restriction Technologies (GURTS) on Agrobiodiversity and Agricultural Production Systems; FAO: Rome, Italy, 2002.

33. Fears, R. Genomics and Genetic Resources for Food and Agriculture; FAO: Rome, Italy, 2007.

34. Heinemann, J.A. A Typology of the Effects of (Trans)gene Flow on the Conservation and Sustainable Use of Genetic Resources; FAO: Rome, Italy, 2007.

35. FAO. Biotechnologies for Agricultural Development-Proceedings of the FAO international Technical Conference on "Agricultural Biotechnologies in Developing Countries: Options and Opportunities in Crops, Forestry, Livestock, Fisheries and Agro-Industry to Face the Challenges of Food Insecurity and Climate Change" (ABDC-10); FAO: Rome, Italy, 2011.

36. FAO. Proceedings of the FAO International Symposium on the Role of Agricultural Biotechnologies in Sustainable Food Systems and Nutrition; FAO: Rome, Italy, 2016.

37. FAO. Report of the Conference of FAO. In Proceedings of the Twenty-Second Session, Rome, Italy, 5-23 November 1983.

38. Gepts, P. Who Owns Biodiversity, and How Should the Owners Be Compensated? Plant Physiol. 2004, 134, 1295-1307. [CrossRef] [PubMed]

39. Kloppenburg, J.R. First the Seed: The Political Economy of Plant Biotechnology; Cambridge University Press: Cambridge, UK, 1988.

40. Mooney, P.R. The Seeds of the Earth: A Private or Public Resource; Inter Pares: Ottawa, ON, Canada, 1979.

41. Keystone Center. Final Consensus Report: Global Initiative for the Security and Sustainable Use of Plant Genetic Resources. In Proceedings of the Oslo Plenary Session (Third Plenary Session), Oslo, Norway, 31 May-4 June 1991.

42. The Crucible Group. People, Plants, and Patents: The Impact of Intellectual Property on Trade, Plant Biodiversity, and Rural Society; International Development Research Centre: Ottawa, ON, Canada, 1994.

43. Ozgediz, S. The CGIAR at 40: Institutional Evolution of the World's Premier Agricultural Research Network; CGIAR: Washington, DC, USA, 2012.

44. IBPGR. Programme and Structure of the International Board for Plant Genetic Resources; International Board for Plant Genetic Resources: Rome, Italy, 1986.

45. IPGRI. The Mulino at Maccarese; International Plant Genetic Resources Institute: Rome, Italy, 2001.

46. Fu, Y.B. The Vulnerability of Plant Genetic Resources Conserved Ex Situ. Crop Sci. 2017, 57, 1-15. [CrossRef]

47. Dulloo, M.E.; Thormann, I.; Fiorino, E.; De Felice, S.; Rao, V.R.; Snook, L. Trends in Research using Plant Genetic Resources from Germplasm Collections: From 1996 to 2006. Crop Sci. 2013, 53, 1217-1227. [CrossRef]

48. FAO. Report of the Third Session of the FAO Panel of Experts on Plant Exploration and Introduction; FAO: Rome, Italy, 1969; pp. 25-28.

49. Frankel, O.H.; Hawkes, J.G. (Eds.) Crop Genetic Resources for Today and Tomorrow; Cambridge University Press: Cambridge, UK, 1975. 
50. Williams, J.T.; Holden, J.H. (Eds.) Crop Genetic Resources: Conservation E Evaluation; Allen \& Unwin: Winchester, MA, USA, 1984.

51. Sonnino, A. Salvaguardia delle risorse genetiche vegetali: Problemi attuali e nuove opportunità. Biol. Ital. 1998, 7, 19-22.

52. FAO. Global Plan of Action for the Conservation and Sustainable Use of Plant Genetic Resources for Food and Agriculture; FAO: Rome, Italy, 1996.

53. Millennium Ecosystem Assessment. Ecosystems and Human Well-Being: Synthesis; Island Press: Washington, DC, USA, 2005. article distributed under the terms and conditions of the Creative Commons Attribution (CC BY) license (http:/ / creativecommons.org/licenses/by/4.0/). 